\title{
No Longer the Fiend but Every Inch a Queen: Reading the Transformation of Lady Macbeth in David Greig's Dunsinane (2010) through the Lens of Adaptation Studies
}

\author{
Pathik Khamrai
}

\begin{abstract}
Adaptation is a way of commenting on an existing piece of literary work and in so doing the process of adaptation often transforms characters to a remarkable extent. The contemporary adaptations of Lady Macbeth, for instance, destabilize the image of 'fiend-like queen' and recreate the character from a revisionist approach, which is characterized by motherly love, freedom and respect. David Greig's Dunsinane shows one such instance in the character of Gruach. This article attempts to show the similarities and differences between Shakespeare's Lady Macbeth and David Greig's Gruach. To achieve this end, a parallel discussion between these two characters has been forwarded. The result is the emergence of a brave, heroic, caring, patriotic Lady Macbeth in the form of Gruach.
\end{abstract}

Keywords: Dunsinane, Gruach, Adaptation, Lady Macbeth, William Shakespeare.

\section{Introduction}

Of late the leading scholars of adaptation studies have highlighted an interesting development by drawing attention to the co-presence of a notable growth of adaptation studies and the absence of proper theorizing regarding the same. For instance, Kamilla Elliott, in her recent monograph on adaptation studies has begun her discussion informing about an "exponential" growth of adaptation studies "since 1990" (Elliott, 2020) but subsequently she also informs that "internationally renowned theorists" of both twentieth and twenty first centuries (even critics like Linda Hutcheon or Robert Stam are named by Elliott in this section) "have struggled to theorize adaptation as satisfactorily as they have theorized other fields" (Elliott, 2020 , p.5). While the present article does not at all propose to address this lack of proper theorizing in its entirety, it aims at drawing attention to the remarkably diverse range that the very process of adaptation can cover by explaining how sequels too can function the same as adaptations, focusing on David Greig's Dunsisane (2010) and its adaptation of the character of Lady Macbeth as well as a particular aspect of Shakespeare's Macbeth.

As suggested above, the present discussion will consider adaptation to be a process primarily marked by its diverse range of effects. Among such effects, however, its contribution in expanding a text's scope will be discussed here by way of using Dunsinane as a case study. Adaptation, therefore, is primarily an extension of one text into others for the present discussion. It is a way of establishing intertextual links with other relevant texts. In so doing, it offers a re - interpretation of a text by making this source text's essence, or at least key elements of it, take the form of another text. In other words, it is mostly about re- 
presenting an existing literary work in a new and (ideally) more nuanced form. The transformation happens across genres: "novels into films; drama into musical; the dramatization of prose narrative and prose fiction; or the inverse movement of making drama into prose narrative" (Sanders, 2005). As Julie Sanders has rightly pointed out that this interconnection and co-existence of the literary texts and other disciplines draw upon the concept of Homi Bhabha's 'hybridity' along with the idea of intertextual linking. Bhabha's notion of 'hybridity' suggests the repetition, relocation and translation of ideas. "This process of relocation can stimulate new utterances and creativity" (Sanders, 2005). The mode of transformation is therefore of a wide variety. As Sanders has pointed out there is a wide range of terms through which adaptation goes on: "version, variation, interpretation, continuation, transformation, imitation, pastiche, parody, forgery, travesty, transposition, revaluation, revision, rewriting, echo" (Sanders, 2005).

Such varied modes of adaptation however require texts of wide familiarity to properly make their effects on the adapted text felt to the viewers. To put it differently, a reader must be familiar with the adapted text in order to understand the subtle resemblances and differences between the new text ensuing from adaptation and the adapted text itself. The adapted text must therefore be one that deals with such themes and ideas which are very much recognizable by a wide number of readers irrespective of the boundaries of time, language, culture, and nation. One such author, whose works are recognized by innumerable readers; and whose works function as the source, in some form or the other, for the author of nearly every single nation, is William Shakespeare. Naturally, Shakespeare has always been the prime focus of adaptation. The adaptation of Shakespearean plays was initiated roughly during the mid seventeenth century England and the succeeding authors have made Shakespearean plays quite acceptable to the readers of his or her own time through permutation and combination of the Shakespearean plots. The adaptation of these plays is not only limited into plays, rather it has been catered into novel, poetry, film, music, animation and many other forms of expression. Though Shakespeare has ceased writing in the early seventeenth century his plays are constantly in the process of making. Noting such recurrence of Shakespeare's works in the world of adaptation, Julie Sanders has identified the Shakespearean canon to be similar to "bodies of texts and source material" like "myth, fairy tale, and folklore" that "depend on a communality of understanding" (Sanders, 2005, p.45). In the following section this study will, however discuss not an adaptation per se but a sequel in order to outline how varied the form and nature of adaptation in general and Shakespearean adaptation can be.

David Greig's play Dunsinane (2010) is arguably the most renowned and thoughtprovoking sequel of Shakespeare's Macbeth. David Greig is one of the most successful Scottish playwrights of the last two decades and more. He has produced around fifty plays including original text, adaptations, and translations. His plays mainly deal with various Global concerns. He has reworked on classical plays and on some European classics. He has adapted Shakespearean plays as well, like Macbeth and The Tempest. In Dunsinane, Greig has re-worked the plot of Macbeth in order to make people understand about the eleventh century Scotland as well as some bigger issues happening in today's world. In the process of portraying these, Greig has come up with the most fascinating, dynamic and challenging adaptation of Lady Macbeth's character in the form of Gruach, the widow of King Macbeth. The play opens just after the end of Shakespeare's Macbeth. Here we see the victorious English general Siward comes with his Army to dethrone the 'tyrant' (Macbeth) and install Malcolm safely as a king; and to make sure that England's border is at peace. Eventually it is revealed that the information he has been given is not totally true, like- the king lasted for fifteen years at a time when Kings were changing in every year; Gruach is not dead; there are some Clans who support Gruach and her son's claim on the royal Throne, etc. Siward is in the middle of a country of which he does not know anything and he does not even want to understand how the Scottish politics functions. Siward tries to restore peace in a country 
which is already devastated by war and in order to do that he gets into brutal guerrilla uprising. The play opens with a conversation of English soldiers working under Siward and it is Siward who enters the stage first among the main characters of the play but overall the play is about Gruach who goes on outwitting Siward throughout the play.

As mentioned above, Dunsinane is in many ways an adaptation of the character of Lady Macbeth and the Shakespearean play itself and the reasons behind describing it so will be explained in this section in the light of Debora Cartmell and Imelda Whelehan's theorizing regarding adaptation. Since the transformation of Lady Macbeth in this play is pivotal in making it not just a sequel but also an adaptation, the discussion will begin mapping her transformation by tracing notable sources as well as afterlives of this character. To begin with, the character of the Shakespearean play itself, in the opinion of William Leigh Godshalk, appears to be inspired from a particular source. It is indeed possible that Shakespeare might have taken some elements to picture Lady Macbeth from Livy's History of Tullia. The character of Tullia is quite similar to that of Lady Macbeth and different in various subtle ways as well. The most considered source of Shakespeare's Macbeth is Holinshed's Chronicles; but some materials have probably also been incorporated by Shakespeare from Livy's account of Tullia in the first book of his History. The similarities and differences between Lady Macbeth and Tullia are an interesting case of study.

Tullia was the younger daughter of king Servius Tullius. Though she was married to Arruns at first, she got attracted to Lucius Tarquinius, The husband of her elder sister. Here Tullia has done something more than Lady Macbeth. Apart from forming an illicit affair with the husband of her sister she has her husband and her sister both killed by Lucius Tarquinius. She appears to be more destructive and more ambitious than Lady Macbeth. In this Roman Legend the king is none other than her own father himself. She instigates her husband to kill her own father so that she could rule the kingdom along with her husband. Tullia said: "Sir if you be the man whom I take my selfe wedded, then I cal you both husband and king" (Godshalk, 1965). Apparently the old King Servius was killed at Tullia's instigation. It shows, she directly took part in the murder, whereas Lady Macbeth could not hold her nerve at the time of the horrific deed. Lady Macbeth had that conscience left within herself that is why she said: "Had he [Duncan] not resembled my father as he slept, I had done't" (Shakespeare, 2013).

Livy has suggested that insanity is the only escape for Tullia's incessant, reckless crimes. Though Livy's Tullia is much prior to the creation of Shakespeare's Lady Macbeth, Lady Macbeth can be regarded as the 'prototype' of Tullia. Though there are some subtle differences between these two characters, "the parallels between Lady Macbeth and Tullia are obvious" (Godshalk, 1965). Shakespeare might have been influenced a bit by the account of Livy as well, along with Holinshed's Chronicles. As observed by Godshalk (1965), "the ambition to have her husband king, the incitement to murder the reigning monarch her direct involvement in the murder, the subsequent madness. That Shakespeare read Livy's account of Tullia is impossible to prove; but in all probability he did" (p. 241). On the basis of these findings of Godshalk, it seems justified to identify Lady Macbeth, that is, the Shakespearean character itself to be a character born from adaptation and additionally detect a potential for being re-shaped in this character type. She is definitely a rebel but in the Shakespearean play or the source identified by Godshalk, her rebellion is not in favour of the greater good. Rather, she appears to fight mostly for personal or at the most her husband's interest.

One such instance of Lady Macbeth fighting for her personal freedom is to be found in Lady Macbeth's character is the 1865 novella of Nicoloai Leskov - Lady Macbeth of the Mtsensk District. Generally considered as Leskov's masterpiece, the novella mainly deals with the subjugated condition of the nineteenth century European women. Lady Macbeth of the Mtsensk District is the "most evocative treatment of pure sexuality Leskov ever wrote, and one of the most powerful in all Russian literature" (Wells, 2001) which "relates the sexual and murderous adventures of Katerina Lvovna, wife of wealthy merchant Zinovy 
Ismailov" (p. 165). Katerina, the Russian avatar of Lady Macbeth is not at all concerned about the well-being of her husband. Rather she has her husband Zinovy murdered with the help of her husband's employee Sergei, with whom she flirts due to her loveless, boring married life under the constant observation of Boris, Zinovy's father. Eventually Katerina has to murder Boris' young nephew Foydor in order to ensure that she remains the sole inheritor of her husband's property. The novella ends with Katerina's downfall. Sergei betrays her out of frustration and turns his attention to two other women. Overall, the novella shows Katerina the daring adulteress getting paid back in her own coin.

In Leskov's version a woman, who is stuck in a loveless marriage, is stepping out of her boundary and plotting and committing murders to enjoy physical satisfaction and love. Unlike Lady Macbeth, Katerina does not long for power and glory. Katerina on the other hand, desires only free love. The novella has also been adapted into an opera with the same title by Dmitri Shostakovich. Dmitri has also put Lady Macbeth in the form of Katerina, in the circumstances of Russian [sexual] revolution. The revolution actually affected a lot of the normal sexual lives of the common people, as Elizabeth A. Wells (2001) states: "the ravages of the war and the Revolution had deprived most people of normal sexual lives. 'Frontabolished sexuality,' the idea of abstention and a weakening of sexual impulses in aid of the revolutionary effort, was popularized in the media" (p. 176). So, here Katerina has nothing to do with her husband's becoming something important or someone special; she plots murders for her own sexual freedom. Katerina indeed has been presented as a character more revolutionary than Lady Macbeth of Shakespeare's play but still her character does not fight for anything other than personal interests.

Further interesting changes in Lady Macbeth's appearance started emerging in the twentieth century and twenty-first century adaptations that differ from that of the earlier by a fine extent. These works, in fact, began a trend of removing the very reference to Macbeth from this character's name and introduced her as an individual with names that helped the character to step out from the Macbeth-Lady Macbeth binary altogether. These contemporary representations appear to be almost completely the opposite of the earlier adaptations. In the earliest instances of these sort of adaptations Gordon Bottomley's play Gruach (1921) shows Gruach (Lady Macbeth is renamed thus)'s craving for emancipation from the confinement she is in. Here Gruach escapes from the subjugated position only to enjoy her freedom and to live her life according to her wishes. As Gruach says: "I would live, so I leave you" (Carroll, 2014). Subsequently, Gruadh (another variant of the name Gruach), in Susan Fraser King's novel Lady Macbeth: A Novel (2008), is very much proud of her royal lineage and also the dignity of her family.

The way Gruadh handles the Danish invasion and her deep commitment to remain intact to the old and original Scottish culture, make her highly patriotic in nature. Gruadh says: "so long as we stay Celts and do not become Roman, or English, or Viking instead. I fear that the Scottish Celts will lose the old wildness, the old ways, for there is much that is good and beautiful in that" (Carroll, 2014, p. 6). Moreover, King's Gruadh emerges as a protective and caring mother. Her maternal instinct always works for the protection of her son Lulach. She has fought very hard to secure a stable future for her son. Similarly in Lisa M. Klein's novel Lady Macbeth's Daughter (2009) and A.J. Hartley and David Hewson's Macbeth: A Novel (2012) the theme of self-effacing maternal love has been dealt with and the character of Macbeth's wife gets presented not as some Lady of a powerful Lord. Instead, she appears as Grelach and Skena, respectively. So, in contemporary adaptations of Lady Macbeth, a rational feminist approach has been observed. Lady Macbeth in these adaptations always tries to come out of her subjugated condition and enjoy a free, respectable and independent life with her rights intact. One can observe a domestic, caring, and patriotic woman in her.

Drawing upon the tradition of replacing Macbeth by his wife, Greig has introduced Gruach as the protagonist in Dunsinane. To borrow Shakespeare's words, Gruach is literally 
a queen in every inch. Greig's play highlights her bravery by putting her in a situation notably similar to that of Lady Macbeth of Shakespeare's play. Just like her predecessor Gruach too has to get involved in bringing a new king to power but unlike Lady Macbeth she does it for her country and in doing so she emerges as a braver woman. Unlike Lady Macbeth, her valour is not limited to her tongue alone. She does not even lose her nerves when she confronts a situation of crisis and hardship like Lady Macbeth, who loses all her composure whenever a fatal moment comes. Gruach has acted like a capable leader throughout the play. No one amongst the conquering English force could actually make her surrender even when she is in the oddest of situations. For instance, just after the end of the battle, towards the beginning of the play, when her clothes are taken away by Egham, she commandingly urges Siward for returning her dresses. And in the conversation between Siward and herself regarding this matter, she literally pushes him backward with her quick, intellectual and confident replies. From the very beginning Gruach lets Siward know that she is a queen and not very easy to be captivated:

SIWARD. What is your place here?

GRUACH. My place here is Queen. (Greig, 2010)

Motherhood was considered as a very subtle and important issue in early modern England. There were so many books on conduct literature giving instructions on mothering. To give an insider view of the mothering during that time, Stephanie Chamberlain writes: "While on the one hand mothers were praised for a selfless devotion to their children, they were likewise condemned for harming the innocents entrusted to their care" (Chamberlain, 2005, p. 73). In the light of this observation the character of Gruach and of Lady Macbeth look like polar opposites. Gruach is a very caring and protective mother. She is always concerned with the safety of her son, especially, given the situation they are in. She is even ready to compromise with or manipulate anyone for the safety of her son. When the English soldier Egham conveys that he wants money by selling some items they have got hold of, the queen instantly becomes ready to help him; but in return she wants her son safely placed with her people in Glen Lyon with an English Patrol. Here, she resembles Gruadh of Susan Fraser King's Lady Macbeth: A Novel (2008). Gruadh, as William C. Carroll (2014) writes: she "fights not only for her own right, and for her lineage back in time, but also for her son's future." (p. 6) On the other hand, Lady Macbeth is ready to thrash "the brains out" (Shakespeare, 2013) of the baby she suckles. The only moments she shows mother like concerns are with her husband Macbeth. One such moment occurs just after the murder of Duncan, when Lady Macbeth treats Macbeth as a fearful child and orders him to "get some water and wash this filthy witness" (Shakespeare, 2013). She also consoles him by saying: "a little water clears us of this deed" (Shakespeare, 2013). Overall, Lady Macbeth of Shakespeare's play is mostly a support for Macbeth. She is not at all bothered by her own condition or that of her country Scotland.

In contrast Gruach fights solely for her country. She understands that Swiard is the only man who can make the difference; rather, he is the only way through which she can come out of the present subdued condition she is in, restore her power and establish the right for her son. So, the first job she needs to do is to have the favour and gain the confidence of Siward. She has not missed any opportunity to egg Siward on against Malcolm. To carry out her purpose Gruach seduces Siward. She uses her sexuality as a weapon to get hold of Swiard, in the following manner:

GRUACH. Ahh! You're an elegant talker, Siward, I'll give you that, but for me -To seduce a man in English - it's like dancing wearing wooden shoes.

SIWARD. Were you seducing me?

GRUACH. It seems so. (Greig, 2010)

While Lady Macbeth loses herself when she faces a direful situation, Gruach is very 
calm and calculative in her every step. She has better foresight than any other character in the play. Which is why, she does not get panicked after the first battle, where she loses her husband. At the meeting of the representatives of the Clans of Scotland, while Siward proposes a marriage between Malcolm and Gruach, she calmly accepts that only to give Siward an impression that she has no other option rather than accepting it. Gruach says: "I have accepted my fate" (Dunsinane, p. 84). Eventually it is shown that she had already planned her next move when the Scottish soldiers come and rescue her during the wedding ceremony. Such moments show that Gruach is more well connected to Scotland's common people than Malcolm, Macduff and of course Siward. On the other hand Lady Macbeth could never win the hearts of common people in that way. Rather, she died remaining essentially a fiendish person.

Gruach loves her country more than she loves herself. The queen wants to see her country completely free from the foreign invaders even if it costs her life. Whatever step she takes, it is for the benefit of her country. There is no such hint that she wants to enjoy power for the sake of enjoying it. She eagerly wants peace to reign over Scotland, which is shown in the exchange between Gruach and Siward at the time when out of frustration Siward tries to kill the child who according to Gruach was the proper heir to the throne:

GRUACH. Kill the child, Siward. Scotland will find another child.

SIWARD. And then I will kill you.

GRUACH. Scotland will find another queen. (Greig, 2010)

The above mentioned transformations make Greig's play an adaptation of Macbeth and in the light of Cartmell and Whelehan's observations, this play appears to be what Cartmell and Whelehan call a "commentary". According to them a commentary is an adaptation that "comment[s] on the politics of the source text" (Cartmell \&Whelehan, 1999, as cited in Sanders, 2005). Since Dunsinane makes a notable comment on Macbeth's politics of limiting the scope of the action to the turmoil within royal families or their close allies like Macbeth, by introducing a queen who fights for the common people of her country, it becomes a significant adaptation of Macbeth, done mostly through transforming the wife of Macbeth into a fearless citizen as well as leader of Scotland.

\section{References}

Carroll, William. C. (2014). The Fiendlike Queen: Recuperating Lady Macbeth in Contemporary Adaptations of Macbeth. Borrowers and Lenders: The Journal of Shakespeare and Appropriation, 8(2), 1-19.

Chamberlain, Stephanie. (2005). Fantasizing Infanticide: Lady Macbeth and the Murdering mother in Early Modern England. College Literature, 32(3), 72-91.

Elliott, Kamilla. (2020). Theorizing Adaptation. Oxford University Press.

Godshalk, William Leigh. (1965). Livy's Tullia: A Classical Prototype of Lady Macbeth. Shakespeare Quarterly, 16(2), 240-241.

Greig, David. (2010). Dunsinane. Faber and Faber.

Sanders, Julia. (2006). Adaptation and Appropriation. Routledge.

Sengupta, S. C. (1984). Macbeth. A. Mukherjee and Co. Pvt. Ltd.

Shakespeare, William. (2013). Macbeth. Bloomsbury.

Wells, Elizabeth. A. (2001). 'The New Woman': Lady Macbeth and Sexual Politics in the Stalinist Era. Cambridge Opera Journal, 13(2), 163-189.

\section{$\underline{\text { Bio-note }}$}


Pathik Khamrai is an independent researcher. He received his post-graduation from Rabindra Bharati University in 2017. His area of interest is Post- Second World War Theatre. He has presented papers in many seminars, conferences and participated in many workshops.

Email id: impk2286@gmail.com 